\title{
Forensic Study on Federal Road Pavement Failures at Rengit and Semerah, Batu Pahat
}

\author{
Syazwan Aiman Sufiyanussuari ${ }^{1}$, Saiful Azhar Ahmad Tajudin ${ }^{1,3^{*}}$, Mohd Fairus \\ Yusof $^{1}$, Nor Azizi Yusoff ${ }^{1,2}$
}

${ }^{1}$ Faculty of Civil and Built Environment, Universiti Tun Hussein Onn Malaysia, 86400 Parit Raja, Johor, MALAYSIA

${ }^{2}$ Research Centre for Soft Soil, Universiti Tun Hussein Onn Malaysia, 86400 Parit Raja, Batu Pahat, Johor, MALAYSIA

${ }^{3}$ Preston GeoCEM Sdn Bhd, 33A, Jalan Universiti 4, Taman Universiti, 86400 Parit Raja, Johor, MALAYSIA

*Corresponding Author

DOI: https://doi.org/10.30880/jsue.2021.01.01.002

Received 24 August 2021; Accepted 11 October 2021; Available online 16 Month 2021

\begin{abstract}
Forensic investigations in engineering term may be conducted to identify the causes of failure to facilitate the design of proper repairs, or to improve the performance or lifespan of a component, assembly, or structure. This paper presents the combination of geotechnical investigation and geophysical survey method as a forensic tool to predict the causes of pavement failure occurred along the coastal area of federal road FT005. The number and type of field testing are varying on each selected study area at Rengit and Semerah, Batu Pahat as this location constructed on soft soil area. Non-destructive testing (NDT) method using electrical resistivity tomography (ERT) were chosen to be applied at the worst severity of the road failure. Three number of resistivity lines of $100 \mathrm{~m}$ and $200 \mathrm{~m}$ were laid out using ABEM Terrameter LS2 with gradient method of electrode arrays covering up to 40-meters depth. Then, further testing of destructive testing (DT) method using borehole drilling conducted near the ERT lines to obtain soil profile with SPT N-value measurement. The disturbed and undisturbed samples were obtained to carried out laboratory test for soil classification. After that, inspection of road pavement layers were implemented at five number of trial pit tests which excavated up to subgrade layer to determine the thickness of the materials used in road construction. Three number of mackintosh probe test were also conducted on top of the subgrade layer after the trenching to obtain the strength of the subgrade layer. The results presented showed that severe longitudinal cracking were the predominant premature failures on the roads studied due to settlement effect of soft soil. The analysis obtained from RES2DINV program stated that the subsurface profiling was dominantly in saturated condition which the resistivity value was less than 100 ohm.m. From the SPT N-value it is observed that, the very soft soil layer is up to $8 \mathrm{~m}$ followed by the soft to stiff clays soil. Another cause of failure was resulted from the differential settlement due to the effect of different design of road construction with varies material used. The reliability and efficiency of the instruments used were also discussed in this study.
\end{abstract}

Keywords: Forensic engineering, soft soils, differential settlement, geophysics, site investigation

\section{Introduction}

In engineering, forensic assessment is the evaluation of materials, products, structures, or breakdown components that were used to determine the causes of failure for the purposes of rehabilitation or mitigation, or to aid a court to determine the facts of an incident or property damage [1-2]. Several forensic assessments have been conducted 
regarding the highway failure evaluation in Johor, Malaysia which focusing on both geotechnical and geophysical practices [3-5]. Experiencing numerous numbers of road deterioration with varieties of types of failures, from surface failures to structural failures had becoming a matter of concern for local authorities in Johor, particularly in the Batu Pahat area. Therefore, the purpose of this paper was to predict the causes of road cracking and differential settlement for remediation purposes.

The large number of defects where longitudinal cracking were seen along the federal route as it was constructed on soft soil area at the west coastal region in Johor. In areas with soft soil, settlement is one of the most common difficulties experienced on the road and it frequently results in severe damage to the pavement structure's overlying layers [6-7]. These defects caused mainly by the differential settlement between the new and the old roads Besides, the increased of permanent loading from the resurfacing from extensive seal coatings and thin overlays, correspondingly causes the rapid settlement. These temporarily surface treatment led to severe pavement failure as the increasing of traffic loading also one of the factors resulting in surface cracking and further settlement [8-12]. Despite periodic surface treatments, the overall pavement condition continues to deteriorate.

To obtain information about the saturated conditions of the soft soil layer, a non-invasive geophysical technique of electrical resistivity tomography (ERT) has been adopted by several researchers as geophysical surveys can provide valuable information about subsurface [13 -16]. Non-destructive methods (NDT) were utilized via electrical resistivity tomography and alongside with boring of holes to carry out the standard penetration test (SPT). On top of the subbase material, the information on road layer profile can be determined using a trial pit and a mackintosh probe test on top of the subbase material. Hence, this study is to determine the resistivity value of the subsurface material together with SPT and Mackintosh probe values of the studied area.

\section{Methodology}

The first field observation has been conducted for this study in June 2020 to survey the failure pavement distress on full scale trial of federal road constructed on soft clay. This study involves three phases via desk study, field survey and testing and data processing. Desk study begins with gathering of previous information regarding study area through existing report, maps, and geological maps of topography area. Then, site survey through filed survey of severe pavement damages and performed geotechnical and geophysical testing. Finally, measurement and data processing using RES2DINV software for ERT was analyses.

The federal road had experiencing very severe surface deformation associate with longitudinal cracking seen along the roads especially at section were loaded with static and dynamic loading. The location where the worst severity found were trenched to verify the thickness road pavement material layers that causing cracking and deformation together with probing test to acquire the strength condition of bound or unbound layers of the subgrade layers. The trenching was excavated using a backhoe excavator not deeper than $1.2 \mathrm{~m}$ or until subgrade layer were found or vice versa. The Mackintosh probe test (MP) was performed on top of the subgrade layer which located at the bottom of the trial pit hole.

Soil investigations were conducted via borehole drilling along with collected of disturbed and undisturbed soil for laboratory test for further soil classification such as moisture content and Atterberg limit [17]. The depth of the borehole is 40-meter. Hence, to create superior subsurface features exploration, this research required both geophysical profiling and geotechnical investigation to undergo further on forensic studies correlation [18]. Therefore, in conjunction to the soil profile from the borehole, ERT survey were also conducted near the borehole location to obtain a thorough subsurface profiling of 40-meter depth. The aim of testing is to obtain subsurface profiling of the 20-meter to 40-meter depth along the problematic area.

\subsection{Study Area and Geology Formation}

The study was conducted along the coastal area of the federal road, FT005, Jalan Johor Bahru - Melaka, which is at Rengit and Semerah, Batu Pahat. Federal Route FT005 is one of the three north-south oriented backbone federal road running along the west coast of Peninsular Malaysia, Malaysia [19]. The 655.85 kilometres (408 mi) federal highway runs from Jelapang, Perak in the north to Skudai, Johor in the south.[20]. Most of the federal roads in Malaysia are two-lane roads constructed with flexible pavement. The width of a single road lane is $3.5 \mathrm{~m}$ with $0.2 \mathrm{~m}$ of road shoulder lane. Signs of defects, deformations and surface distresses at a certain stretch can be seen along the route. Fig. 1 shows the longitudinal cracking occurred at Rengit and Semerah. The distance between the Semerah and Rengit site locations is about $51.2 \mathrm{~km}$, which is approximately an hour's drive as shown in Fig. 2. 

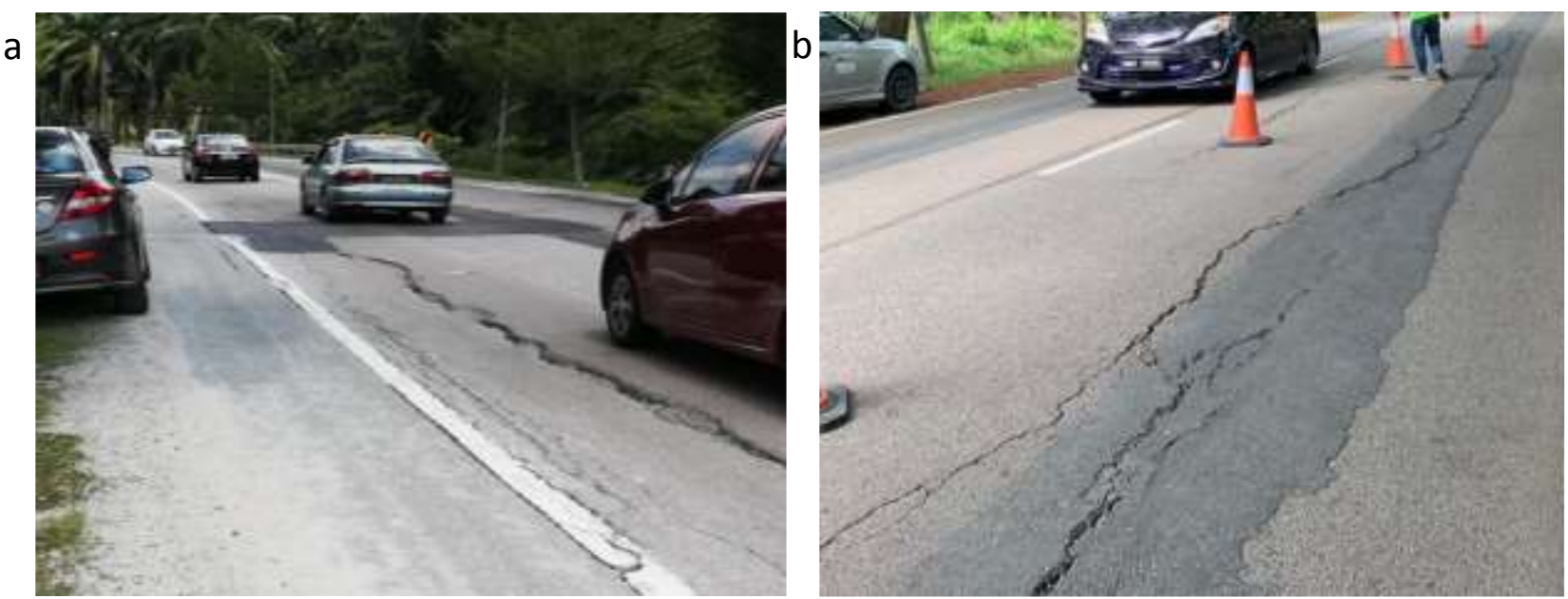

Fig. 1 - Longitudinal cracking found along FT005 (a) Rengit and (b) Semerah

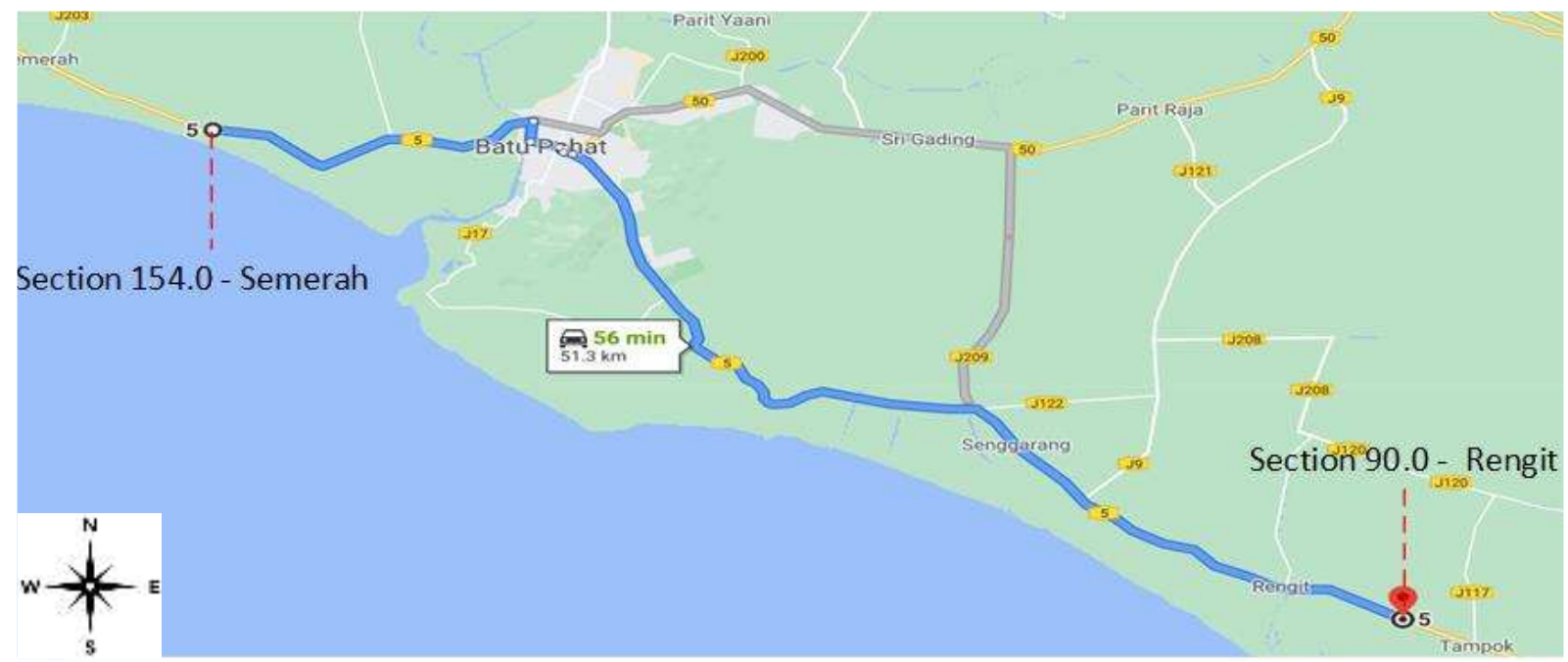

Fig.2 - Route from Rengit to Semerah in Batu Pahat district

The soft soil samples were obtained from the borehole 1 (BH1). BH1 was located at $1^{\circ} 400^{\prime} 6.1^{\prime \prime} \mathrm{N}$ and $103^{\circ} 10^{\prime} 44.5^{\prime \prime E}$. There were three (3) electrical resistivity survey lines referred as RL1 and RL2 at Rengit, and RL3 at Semerah. RL1, a 200-meter survey length was conducted at the edge of road shoulder lane towards Johor Bahru starting from northwest $1^{\circ} 40^{\prime} 9.54^{\prime \prime} \mathrm{N}$ and $103^{\circ} 10^{\prime} 38.89^{\prime \prime} \mathrm{N}$ and ending at southeast $1^{\circ} 40^{\prime} 6.72^{\prime \prime} \mathrm{N}$ and $103^{\circ} 10^{\prime} 44.27^{\prime \prime} \mathrm{N}$. While, for RL2, a 100-meter survey length was conducted on the lane towards Melaka starting from northwest $1^{\circ} 40^{\prime} 8.48^{\prime \prime} \mathrm{N}$ and $103^{\circ} 10^{\prime} 39.95^{\prime \prime} \mathrm{N}$ and ending at southeast $1^{\circ} 40^{\prime} 7.17 \mathrm{~N}$ and $103^{\circ} 10^{\prime} 42.62^{\prime \prime} \mathrm{N}$. For electrical resistivity, RL3 was conducted at the edge of road shoulder lane towards Melaka starting from northwest $1^{\circ} 51^{\prime} 21.55^{\prime \prime} \mathrm{N}$ and $102^{\circ} 50^{\prime} 1.04^{\prime \prime} \mathrm{N}$ and ending at southeast $1^{\circ} 51^{\prime} 20.72^{\prime \prime} \mathrm{N}$ and $102^{\circ} 50^{\prime} 7.47 " \mathrm{~N}$. BH1 was conducted at the Rengit site near the centerline of RL2, which is about 5-meter apart. Trial Pits and Mackintosh Probe were referred ad TP1, TP2, TP3 and MP1 and MP2 respectively were conducted at Rengit at the centerline RL2. Meanwhile, the Trial Pit and Mackintosh Probe of TP4, TP5 and MP3 at Semerah were conducted on the road lane toward Johor Bahru. The number and type of field testing conducted were stated along the location as shown in Table 1

Table 1 - Location, type and number of field testing conducted

\begin{tabular}{|c|c|c|c|c|c|c|}
\hline $\begin{array}{c}\text { Site } \\
\text { location }\end{array}$ & $\begin{array}{l}\text { Resistivity } \\
\text { Lines (RL) }\end{array}$ & $\begin{array}{c}\text { Profile } \\
\text { Length } \\
\text { (m) }\end{array}$ & $\begin{array}{c}\text { Profile } \\
\text { depth (m) }\end{array}$ & $\begin{array}{c}\text { No. } \\
\text { Borehole } \\
\text { (BH) }\end{array}$ & $\begin{array}{l}\text { No. Trial } \\
\text { Pit (TP) }\end{array}$ & $\begin{array}{c}\text { No. } \\
\text { Mackintosh } \\
\text { Probe (MP) }\end{array}$ \\
\hline Rengit & $\begin{array}{l}\text { RL1 } \\
\text { RL2 }\end{array}$ & $\begin{array}{l}100 \mathrm{~m} \\
200 \mathrm{~m}\end{array}$ & $\begin{array}{l}20 \mathrm{~m} \\
40 \mathrm{~m}\end{array}$ & 1 & 3 & 2 \\
\hline Semerah & RL3 & $200 \mathrm{~m}$ & $40 \mathrm{~m}$ & - & 2 & 1 \\
\hline
\end{tabular}


The geology at Rengit and Semerah, Batu Pahat, Johor belongs to Quaternary unconsolidated marine clay. It consists of a deposit of clay, silt, sand, and peat with minor gravel as shown in Fig. 2. The characteristics of Quaternary deposit are soft, unconsolidated and high groundwater table. Malaysia's soft soil is often classified as quaternary sediments made up of marine clay deposits and organic or peat soils [21].

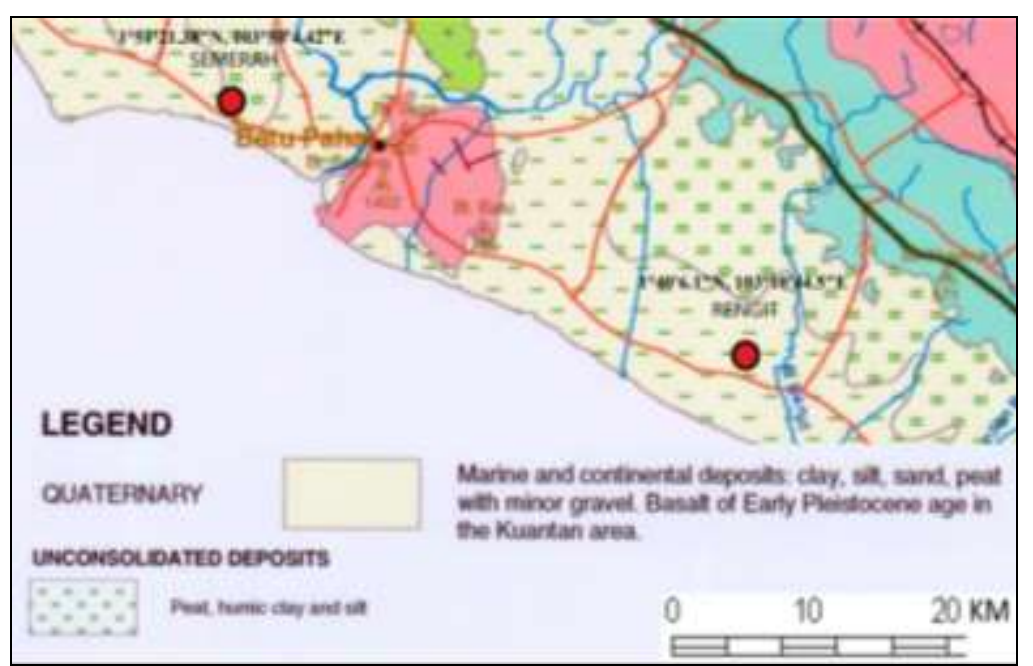

Fig. 2 - Geology map of FT005, Rengit and Semerah, Batu Pahat, Johor [21]

\subsection{Data Acquisition and Processing}

ERT was carried out using ABEM Terrameter LS2 with gradient method of electrode arrays that measures depth coverage up to 40-meters below the central part of the profile and decreases with distance away from the center building in a pseudo section of electrical resistivity imaging. Several equipment which includes 4 units of multipurpose cable, 64 units of jumper cable, 61 units of stainless-steel electrode, 2 units of cable connector, and 1 unit of 12 -volt battery. The profile lines were measured from distance between first electrode position, sharing electrode position, center of Terrameter LS2, RES2DINV program is used to process the converted raw data from geophysical survey was conducted using electricity resistivity test method and the analysis employed using gradient protocols [2223]. The resistivity results were interpreted based on resistivity value as shown in Table 2.

Table 2 - Resistivity value interpretation [24]

\begin{tabular}{ccc}
\hline Resistivity Value $(\Omega \mathrm{m})$ & Interpretation \\
\hline $1-100$ & Legends & $\begin{array}{c}\text { Zone of saturated soil } \\
\text { Zone of unsaturated } \\
\text { soil }\end{array}$ \\
\hline
\end{tabular}

\section{Result and Analysis}

\subsection{Subsurface Profiling}

The resistivity analysis of subsurface condition of 20-meter and 40-meter depth based on the resistivity length from the surfaces. By referring 2D image from gradient protocol, the different color of layers indicates the layer's resistivity which is in the range between $0.0 \mathrm{ohm} . \mathrm{m}$ (ohm meter) to $100.0 \mathrm{ohm} . \mathrm{m}$. It shows that imported soil has a different layer compared to the original soil. It may be shown this range consists of several colors representing a type of soil which have high resistivity. The blue layers shown the 2D image were clay soil, it was believed the soil were saturated as the groundwater level were at 1.0 meter from surfaces.

Fig. 3(a) shows the result for the survey RL1 at a 200-meter length of a 40-meter depth profile. The majority of the resistivity value is less than $100 \mathrm{ohm} . \mathrm{m}$, which indicates that the subsurface ground is in a saturated condition. The resistivity value slightly increases with depth from $0.5 \mathrm{ohm} . \mathrm{m}$ to $100 \mathrm{ohm} . \mathrm{m}$. The resistivity tomography shows that the soil profile can be divided into three layers, which are below $30 \mathrm{ohm} . \mathrm{m}$, between 30 and $60 \mathrm{ohm} . \mathrm{m}$, and more than 60 ohm.m. It shows that the soil decreases its porosity and increases in dry density with depth. It is worth to note that the electrical resistivity depends on many factors such as porosity, the salinity/chemical of the pore fluid, dry density, degree of saturation, particle shape and orientation, pore structure, clay content and mineralogy.

Fig. 3(b) shows the result for the survey RL2 at a 100-meter length of a 20-meter depth profile. The most of the resistivity value is less than $100 \mathrm{ohm} . \mathrm{m}$, which indicates that the subsurface ground is in a saturated condition. The 
resistivity value slightly increases with depth from $0.5 \mathrm{ohm} . \mathrm{m}$ to $500 \mathrm{ohm} . \mathrm{m}$. However, the top layer shows high resistivity of up to $500 \mathrm{ohm}$.m due to the layers of pavement and concrete slab. Below the pavement, the soil resistivity tomography profile can be divided into three layers, which are below $30 \mathrm{ohm} . \mathrm{m}$, between 30 and $60 \mathrm{ohm} . \mathrm{m}$, and more than $60 \mathrm{ohm} . \mathrm{m}$. It shows that the soil decreases its porosity and increases in dry density with depth. The borehole result from 1.5-meters to 15.0-meters indicates a very soft clay from the borehole (BH1 at Section 90.0 - Rengit).

Fig. 3(c) shows the result for the survey RL2 at a 200-meter length at a 40-meter depth profile. The most of the resistivity value is less than $100 \mathrm{ohm} . \mathrm{m}$, which indicates that the subsurface ground is in a saturated condition. The resistivity value slightly increases with depth from $0.5 \mathrm{ohm} . \mathrm{m}$ to $100 \mathrm{ohm} . \mathrm{m}$. The top layer shows high resistivity value of up to $500 \mathrm{ohm} . \mathrm{m}$. The resistivity tomography shows that the soil profile can be divided into two layers, which is below $30 \mathrm{ohm} . \mathrm{m}$, and above $30 \mathrm{ohm} . \mathrm{m}$. It shows that the soil decreases its porosity and increases in dry density with depth. It was noticed that the lens of high resistivity value goes up to $300 \mathrm{ohm} . \mathrm{m}$ between depths of 5 and 25 meters. The ERT results show a good agreement as depicted in the geological survey of Malaysia's geological map of quaternary unconsolidated marine clay [21].
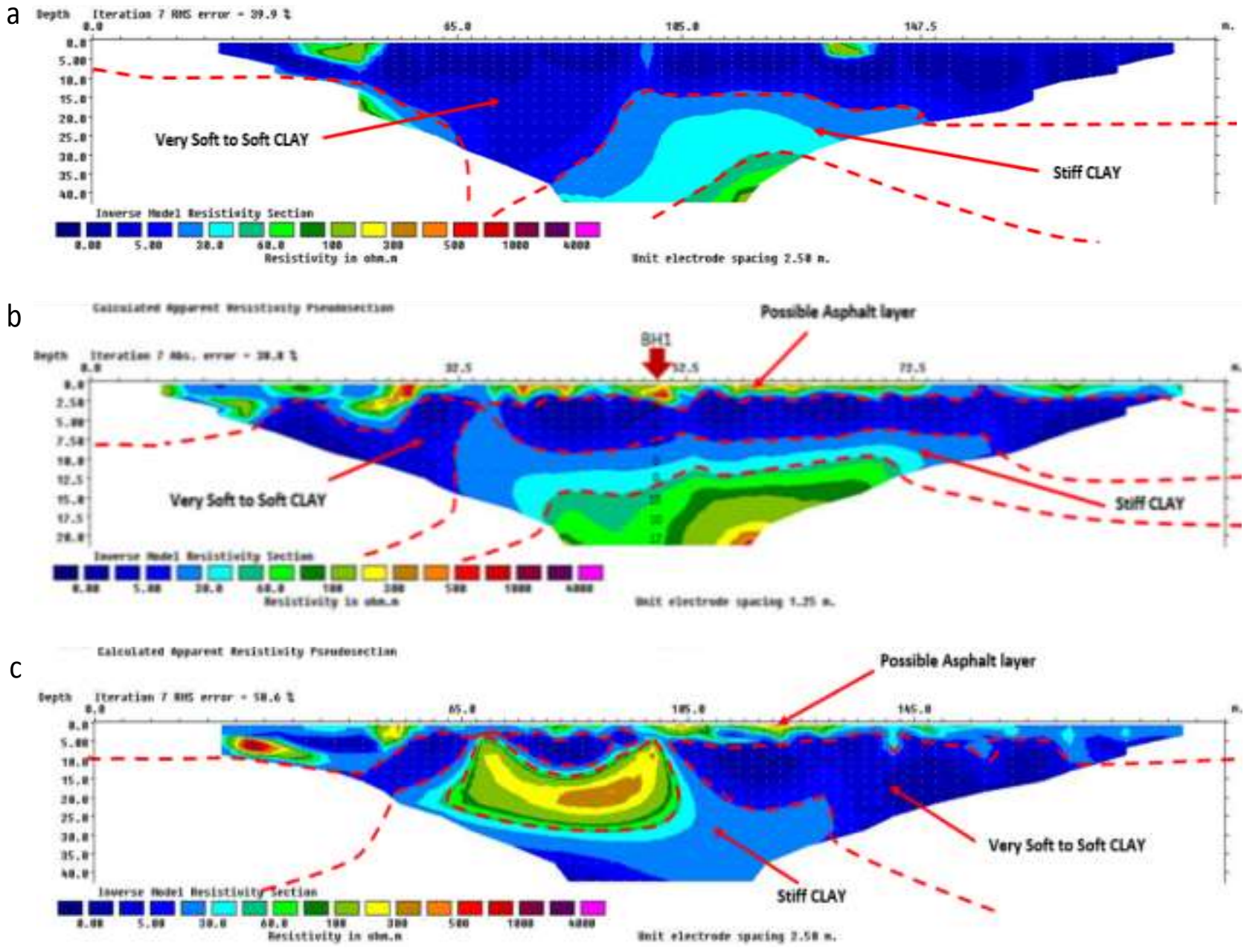

Fig. 3 - 2-D images produced using gradient protocols at (a) RL1 - 200m at Rengit (b) RL2 - 100m at Rengit (c) RL3 - 200m) at Semerah

\subsection{Soil Profile from BH and MP Tests}

The soil profile, SPT-N value obtained from the BH1 in accordance with the procedures in BS 1377: 1990, is shown in Fig. 4 along with the M-value from MP tests. It is observed that the $\mathrm{N}$ value of the soft inorganic clay layer is very low, which is 0 from the surface until 15-meter depth. The top two layers of the soil sample obtained were dark greenish gray very soft inorganic clay and greenish grey soft inorganic clay were compressed due to the construction of the road embankment. Moreover, the bottom two layers of light greenish grey medium stiff inorganic clay and light brown very stiff inorganic clay indicates that the compression still occur until termination depth at 42-meter as referred to JKR specification. Furthermore, the MP instrument measures the blow per penetration of the structural properties of bearing capacity of subgrade layer which performed on the same location of trial pit test. Therefore, the asphalt layer needs to be trenched first. The results show that the bearing capacity of the subgrade was in poor condition at soft soil 
layer as the blows were recorded very low. The MP testing confirmed that the subgrade layer was weak; in fact, the MP penetrated the subgrade shows a consistency of very soft to stiff clay with 0.0 to 200.0 (kPa) of unconfined compressive strength as shown in Table 3. Although the MP layer shows a vary stiffness, however the results of MP were stop early as the result obtained were already correlate to borehole profile and these correlations are not used in the proportioning of foundations. They can at best use as an approximate pointer to the consistency and shear strength of cohesive soils [25].

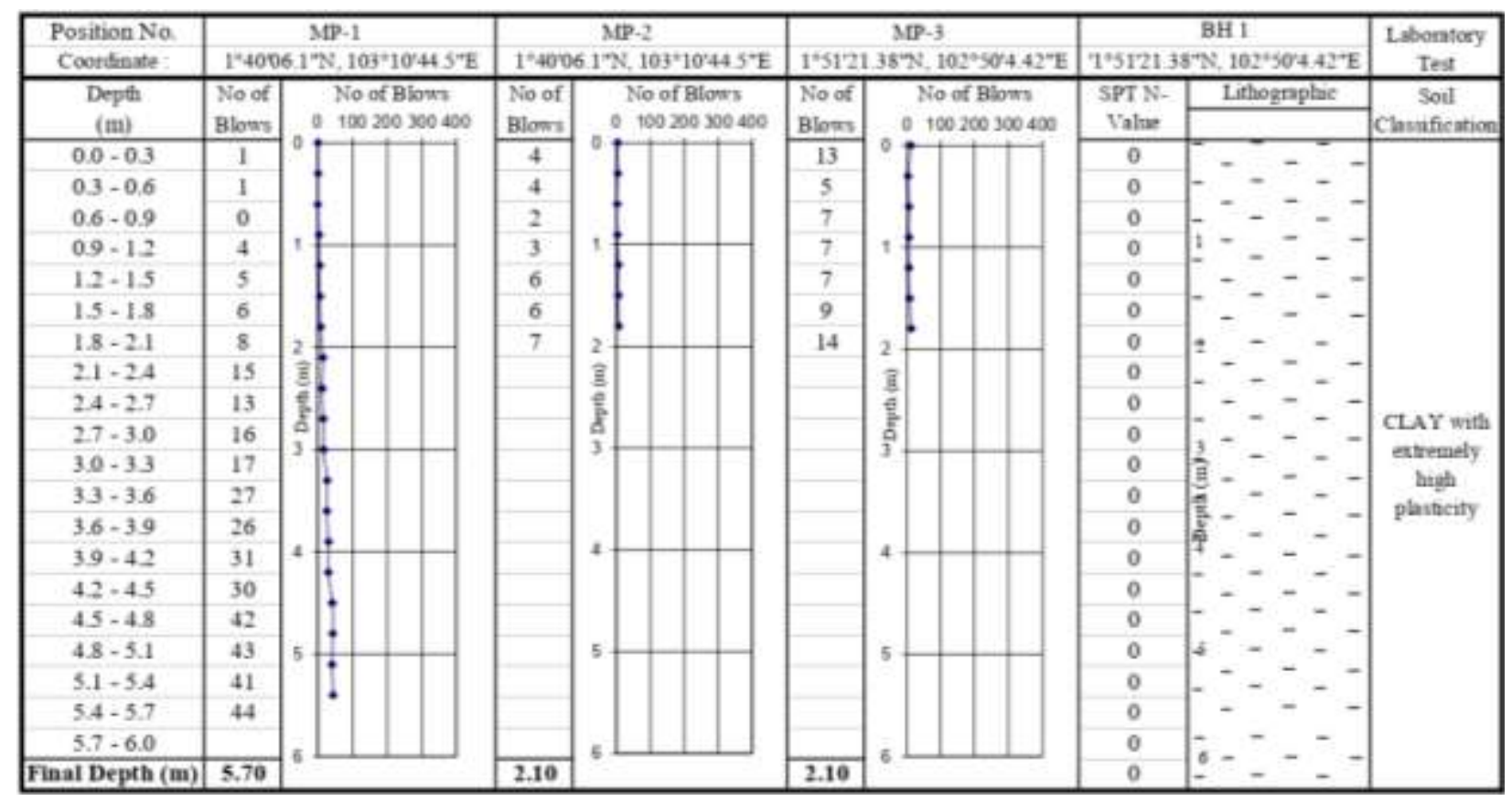

Fig. 4 - Geology map of FT005, Rengit and Semerah, Batu Pahat, Johor

Table 3 - Correlation for cohesive soils [25]

\begin{tabular}{cccc}
\hline $\begin{array}{c}\mathbf{N} \\
(\text { Blows/m) }\end{array}$ & Consistency & $\begin{array}{c}\text { Unconfined Compressive } \\
\text { strength }(\mathbf{k P a})\end{array}$ & $\begin{array}{c}\text { JKR or Mackintosh } \\
\text { Probe (Blows/m) }\end{array}$ \\
\hline $0-2$ & Very soft & $0.0-25$ & $0-10$ \\
\hline $2-4$ & Soft & $25-50$ & $10-20$ \\
\hline $4-8$ & Medium (firm) & $50-100$ & $20-40$ \\
\hline $8-15$ & Stiff & $100-200$ & $40-70$ \\
\hline $15-30$ & Very stiff & $200-400$ & $70-100$ \\
\hline$>30$ & Hard & 400 & 100 \\
\hline
\end{tabular}

Based on the boreholes result indicated the presence of clay deposits at the site with a thickness of $16.5 \mathrm{~m}$ of very soft clay. Stiff to very stiff clay layer was found up to a depth of $40.5 \mathrm{~m}$. This layer contains very extremely high plasticity. Moreover, the majority of the resistivity value of RL1 and RL2 (Rengit) is less than $100 \mathrm{ohm} . \mathrm{m}$, which indicates that the subsurface ground is in saturated condition. The borehole data supports the electrical resistivity result, which shows lower SPT-N values at 16.5-meter depth. The majority of the resistivity value of RL3 (Semerah) is less than $100 \mathrm{ohm} . \mathrm{m}$, which indicates that the subsurface ground is also in saturated condition. The soil profile obtained from BH1 matches well with the data obtained from RL2. Thus, the ERT profile shows the exact variation of the soil profile. Hence, it is safe to assume that the soil profile at Rengit and Semerah is the same based on the RL1, RL2 and RL3 profile and the geology map that is considered Quaternary unconsolidated sediment consists of marine clay.

\subsection{Trial Pit Result at Rengit}

The pavement distress shows longitudinal cracking, indicating highly deteriorated areas along the roadways at the center of both lanes. In this case, TP1 was dug $5 \mathrm{~m}$ away from TP2. TP2 and TP3 points were excavated together sideby-side, as shown in Fig. 5. The concrete slab is underlain by reinforcing fabric of steel (BRC reinforcement), which was found at TP2 and TP3 in a depth of $600 \mathrm{~mm}$ and a width of $2.3 \mathrm{~m}$. The gap between the concrete slab is 1 -inch $(24.5 \mathrm{~mm})$ at the centerline of the roadways. The concrete slab layer was constructed between both centers of the road lane. During the widening road project, the different methods from the existing construction were adopted geotextile between the crusher run layer and the treated subgrade $(500 \mathrm{~mm}-600 \mathrm{~mm})$ material. 


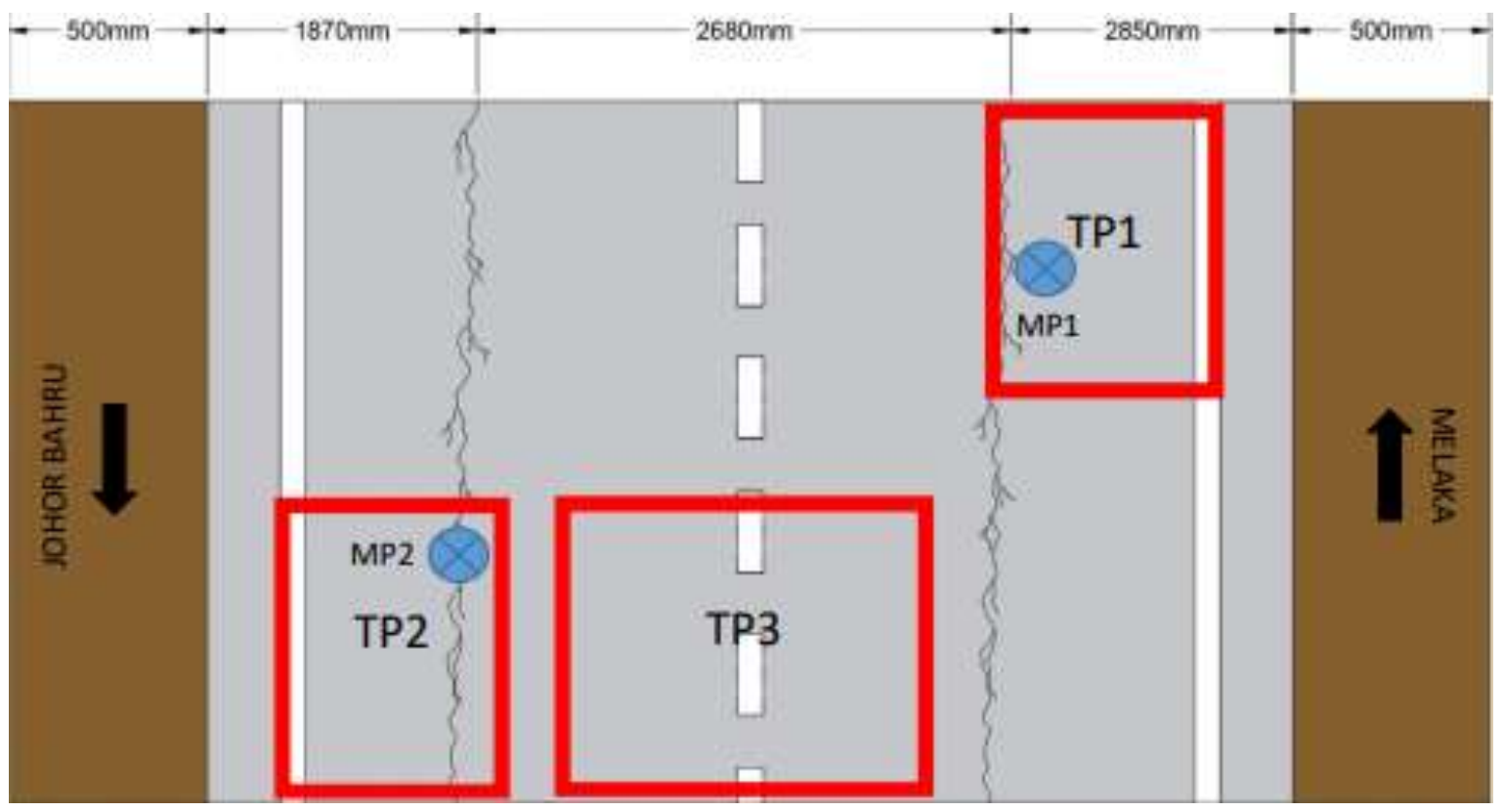

Fig. 5 - Trial Pit and Mackintosh Probe location Section 90 - Rengit

Illustration in Fig. 6 show that the longitudinal cracking seen from the center of the side lane dispersed downward to the asphaltic layer only. A longitudinal cracking dispersed on the pavement surface caused by differential settlement at the edge of the concrete slab was due to the different layers of material for road widening construction. The material used for road widening are geotextile layers and are treated as subgrade material. Meanwhile, the existing road was constructed using concrete slabs with BRC reinforcement underneath, followed by soft soil. Another longitudinal cracking dispersed only on the pavement surface caused by differential settlement at the center of road was due to the 1-inch gap between the reinforced concrete slabs. However, with a very high groundwater table of 1.0meter, lateral (horizontal) force also tends to occur. Visual inspection indicates that the pavement is structured at TP1 \& TP3 to have 4 layers; E1 Asphaltic Layer (400mm-thick), E2 Crusher Run (170mm), E3 Geotextile (30mm-thick) and E4 Treated subgrade $(500 \mathrm{~mm}-600 \mathrm{~mm})$. The pavement at TP2 is structured to have 5 layers; E1 Asphaltic Layer (400mm-thick), E2 Crusher Run (200mm), E3 Concrete Slab (150mm- thick), E4 BRC Reinforcement and E5 Soft Soil.

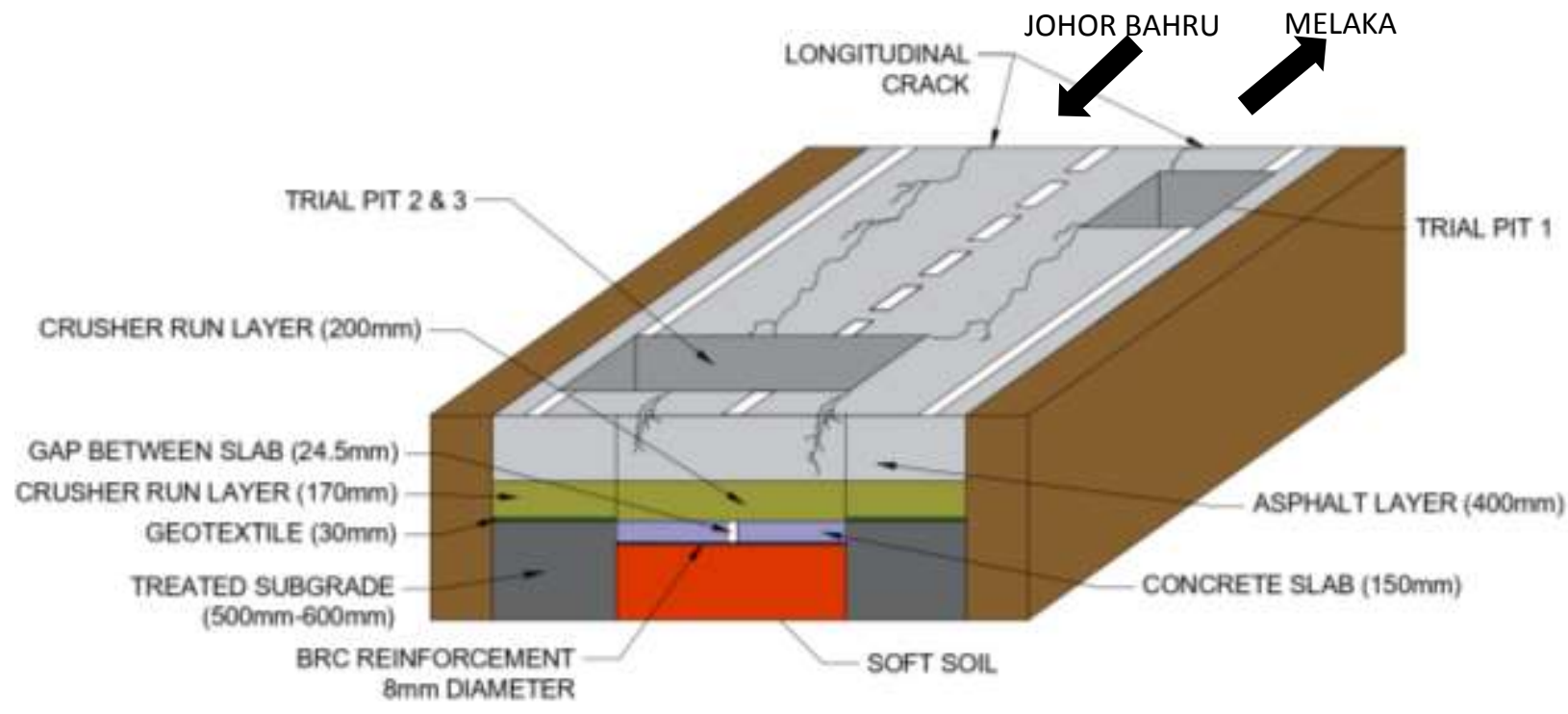

Fig. 6 - Cross section of the Trial Pit hole excavated at Section 90.0 (Rengit) 


\subsection{Trial Pit Result at Semerah}

The pavement distress shows longitudinal cracking, indicating highly deteriorated areas along the roadways at one lane. In this case, TP 4 and TP 5 points were dug together side-by-side, as shown in Fig. 7.

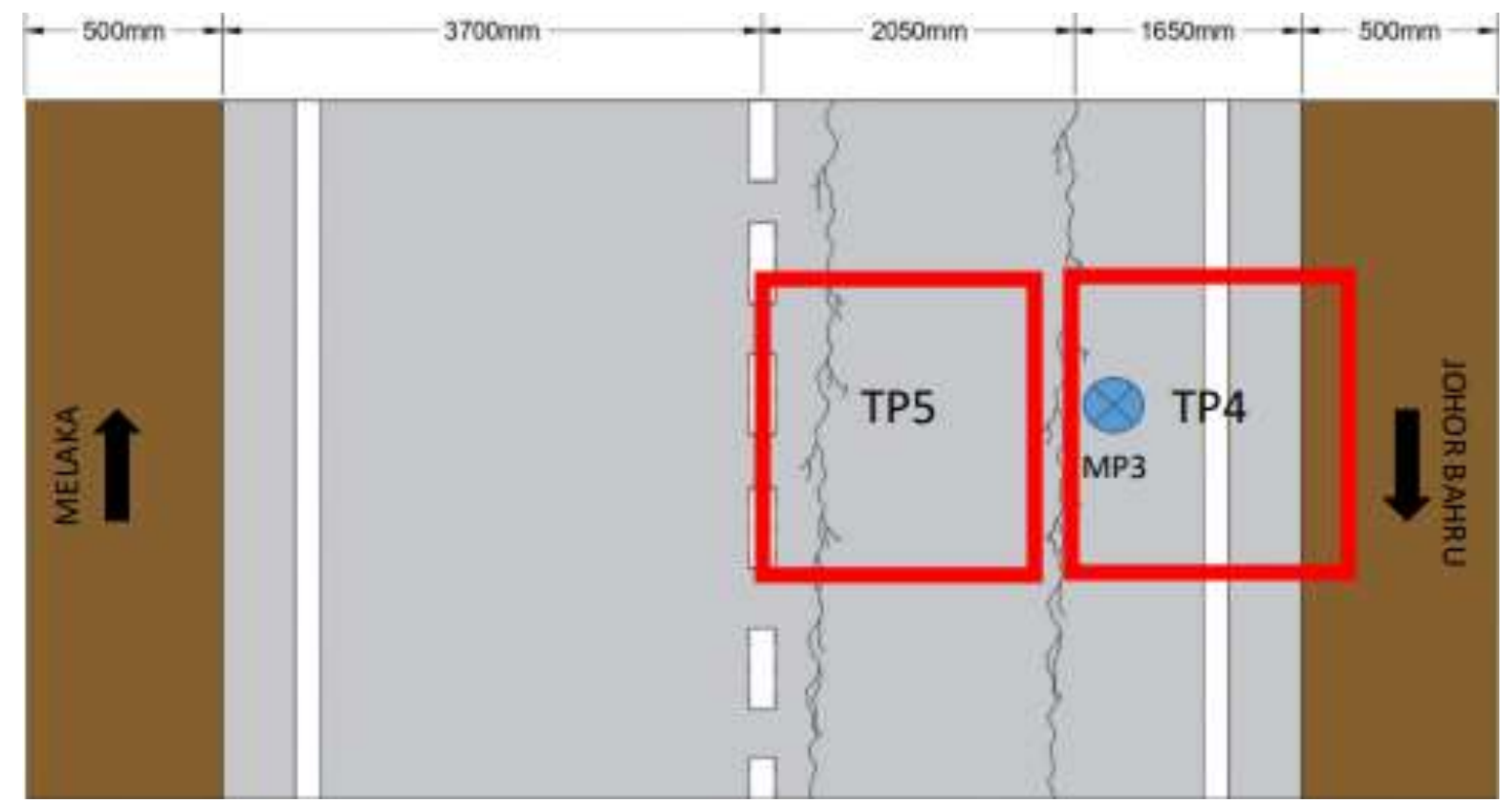

Fig. 7 - Trial Pit and Mackintosh Probe location Section 90 - Rengit

Illustration in Fig. 8 shows that the concrete slab layer was found from the road shoulders to the centerline of roadways, below the crusher run layer on both sideways without a gap. The concrete slab layer in Semerah was found along the road without BRC reinforcement underneath it. A longitudinal cracking dispersed from the surface of the road is due to the failure of a concrete slab, which was made by solid concrete material without any reinforcement. Therefore, any increment of loading can cause concrete composite material to have less strength under tensile strength. In addition, the pumping effect due to traffic load, traffic high speed, traffic volume, and increase of surcharge loading (resurface pavement) can deflect the concrete slabs and rupture near the edge of the concrete slab. Moreover, heavy loading of crusher run layer of material using larger gravel, such as cobble and pebble, might also be possible causes of excessive loading. Furthermore, the road was constructed on a high embankment of the road. Therefore, slope stability failure might occur and lead to soil tension crack. This tension crack may cause the whole structure of pavement to fail. In the analysis, the pavements at TP 4 \& TP5 were structured to have 4 layers; E1 Asphaltic Layer, E2 Crusher Run layer, E3 Concrete Slab and E4 Soft Soil.

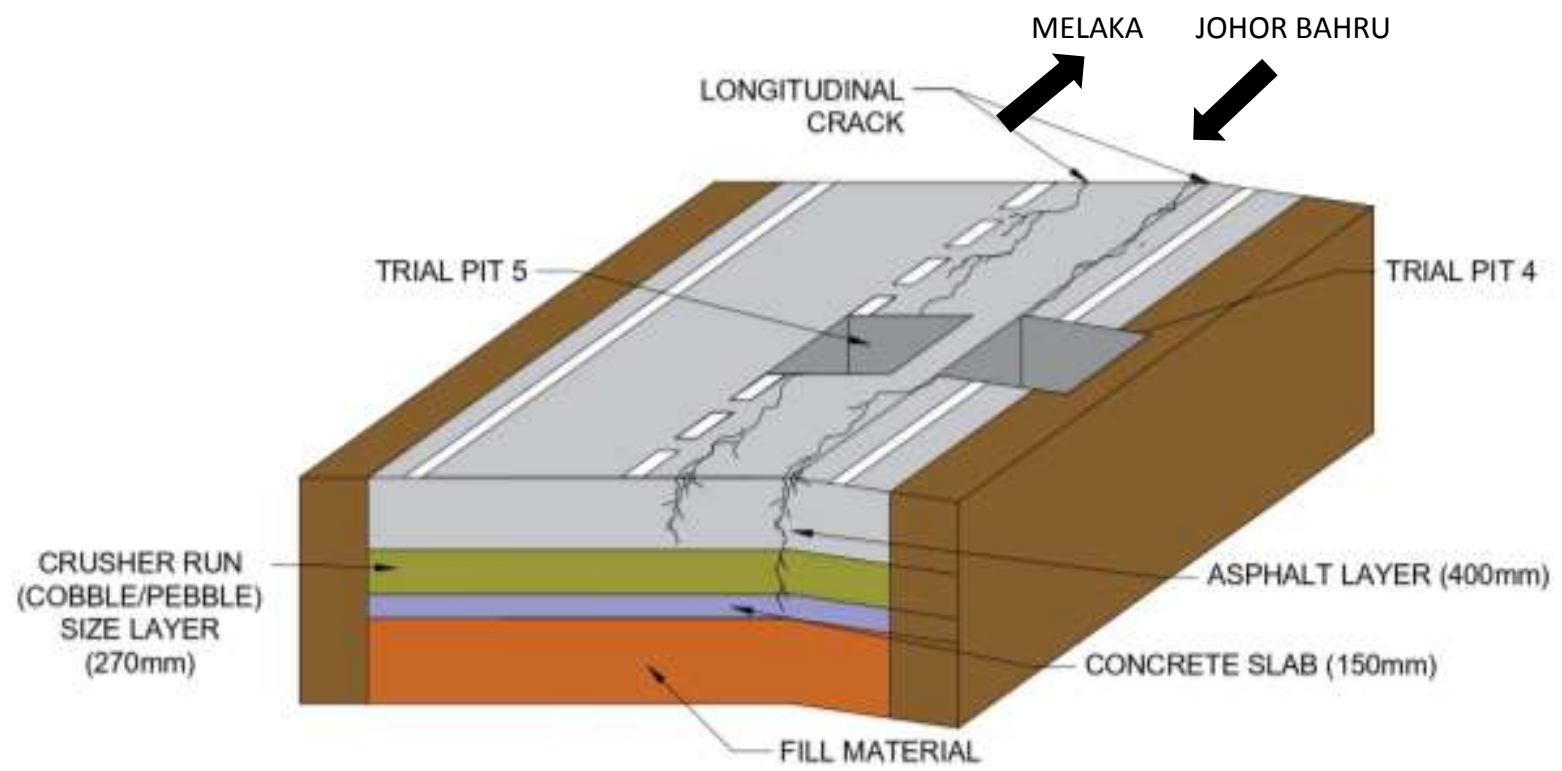

Fig. 8 - Cross Section of Trial Pit 4 \& 5 in Section 154.0 (Semerah) 


\section{Conclusion}

Based on the investigation, the soil subsurface profiling at Rengit and Semerah shows a very soft to stiff clay soils. The soil profiling from borehole and resistivity values displays an identical consistent result. This is also supported by the geological map that the research area is considered as Quaternary unconsolidated sediment consisting of marine clay. Therefore, the settlement is likely to be factor of the road failure as the federal road were built on top of soft soils area. From the trial pit excavation, it was found the differential settlement along the cross section of the road due to different construction method. Furthermore, there were a ruptured slab found along the longitudinal cracking on the surface. Ensuring the comfortability and safety of road users, damaged areas have been repaired over the years by a concession company using resurfacing method. This has caused the thickness of the pavement to increase up to $0.4 \mathrm{~m}$ from the road surface. Thus, the increased of the static load on the road due to resurfacing has triggered other problems related to the weak condition of subgrade. In conclusion, improper construction practices using varies material had contributed to the failure of the road. Generally, several road improvement attempt can be considered on soft soil construction which include strengthened the soil and stabilized the soil.

\section{Acknowledgement}

The authors would like to thank the Universiti Tun Hussein Onn Malaysia for supporting the study through Geran Penyelidikan Pascasiswazah (GPPS) Grant Vot. H737, Jabatan Kerja Raya Baru Pahat, Pusat Kecemerlangan Kejuruteraan dan Teknologi JKR (CREaTE) and Preston GeoCEM Sdn. Bhd spin-off company of Universiti Tun Hussein Onn Malaysia.

\section{References}

[1] Zainal Abidin, M. H, Madun, A, Ahmad Tajudin, S. A, and Ishak, M F. (2017). 'Forensic assessment on near surface landslide using electrical resistivity imaging (ERI) AT Kenyir Lake area in Terengganu, Malaysia', Procedia Engineering, 171, pp. 434-444

[2] Van der Geer, J., Hanraads, J. A. J., \& Lupton, R. A. (2000). The art of writing a scientific article. Journal of Science Communication, 163, 51-59

[3] Ahmad, A. (2018). Pile Eccentricity Check for Common Pile Group Arrangement, 'Forensic Civil Engineering Seminar 2018 (ForCES 2018), 29th \& 30th October 2018 Kuala Lumpur Malaysia’,pp 1-3

[4] Jestin Bt. Jelani (2006) Forensic Studies on Rural Road Pavement Failures in Parit Raja Vicinity Kolej Universiti Teknologi Tun Hussein Onn. Master Thesis

[5] Andi Norashikin Bachok. (2008). Numerical Modelling in Investigation of Road Failure on Malaysia Peat Soil, Kolej Universiti Teknologi Tun Hussein Onn. Master Thesis

[6] Wan Hashim, W.A and Masirin, M. I. (2016). 'Site investigation as a geotechnical forensic tool for road embankment performance evaluation.', Engineering Postgraduate Conference (EPC) 2008, 1(4), pp. 1-6

[7] Che Mamat, R., Kasa, A. and Mohd Razali, S. F. (2019). 'A Review of Road Embankment Stability on Soft Ground: Problems and Future Perspective', IIUM Engineering Journal, 20(2), pp. 32-56

[8] Mohamad, N, Razali, C. E, Hadi, A. A. A, and Som P. P. (2016). 'Challenges in Construction Over Soft Soil Case Studies in Malaysia’, IOP Conference Series: Materials Science and Engineering, 136(1), p. 12002

[9] Huang Qinlong, Ling Jianming, and Tang Boming. (2004). On distress characteristics and mechanism in road widening engineering. Journal of Tongji University (Natural Science), 32 (2): 197-201 (in Chinese)

[10] Weng Xiaolin, Li Lintao, Zhang Liujun. (2010). Model experimental research on wetting damage mechanism of widening loess roadbed. Chinese Journal of Rock Mechanics and Engineering, 29 (5): 1075- 1081 (in Chinese)

[11] Han J, Akins K. (2002). Use of geogrid-reinforced and pile-supported earth structures. Proceedings of International Deep Foundation Congress, ASCE. Orlando, 668-679

[12] Habib H. A. A., Brugman M. H. A., Uilting B. G. J. (2002). Widening of Road N247 founded on a geogrid reinforced mattress on piles. Proceedings of the Seventh International Conference on Geosynthetics. 369-372

[13] Zhang Dingwen, Liu Songyu (2004), The problems and countermeasures of highway widening project on soft ground. Subgrade Engineering, (3): 34-38 (in Chinese)

[14] Boyle, A., Wilkinson, P. B., Chambers, J. E., Meldrum, P. I., Uhlemann, S., and Adler, A. (2018). Jointly reconstructing ground motion and resistivity for ERT-based slope stability monitoring. Geophys. J. Int. 212 (2), $1167-1182$

[15] Gunn, D. A., Chambers, J. E., Dashwood, B. E., Lacinska, A., Dijkstra, T., Uhlemann, S., Swift, R Kirkham, M, Milodowski, A, Wragg, J, and Donohue, S. (2018). Deterioration model and condition monitoring of aged railway embankment using non-invasive geophysics, Construction and Building Materials, 170(5), 668-678

[16] Pasierb, B., Grodecki, M., and Gwóźdź, R. (2019). Geophysical and geotechnical approach to a landslide stability assessment: a case study. Acta Geophysica. 67 (6), 1823-1834 
[17] Tarmizi, T, Saad, R, Mohd Muztaza, N, Ismail, N. A, Saidin, M. M, and Mohamad, E. T. (2016). 'Integration of SPT (N-Value), Mackintosh Probe (M-Value) and Resistivity values for Soft Soil Assessment', in Jurnal Teknologi, 78 (8-6) 87-92

[18] Hutchison C. S and Tan D. N. K. (2009). The Geology of Peninsular Malaysia, Geology Society of Malaysia, Department of Geology, University of Malaya, 1-479

[19] Martinho, E. and Dionísio, A. (2014). 'Main geophysical techniques used for non-destructive evaluation in cultural built heritage: a review', Journal of Geophysics and Engineering, 11(5), pp. 1742-2132

[20] "Kenali rangkaian laluan tulang belakang negara kita". Blog Jalan Raya Malaysia (in Malay). 2014-11-01. Retrieved 2015-11-18

[21] "Statistik Jalan (Edisi 2013)". Statistik Jalan. Kuala Lumpur: Malaysian Public Works Department: 16-64. 2013. ISSN 1985-9619

[22] Duraisamy, Y., Huat, B. B. K., \& Aziz, A. A. (2007). Engineering properties and compressibility behavior of tropical peat soil. American Journal of Applied Sciences, 4(10), 768-773

[23] ASTM D6431-18, Standard Guide for Using the Direct Current Resistivity Method for Subsurface Site Characterization, ASTM International, West Conshohocken, PA, 2018

[24] Mohamed, A.-M. O. Paleologos, E. K., Ghrefat, H, and Howari, F. M. (2021). 'Chapter 6 - Site investigation', Pollution Assessment for Sustainable Practices in Applied Sciences and Engineering. Butterworth-Heinemann, pp. 289-354

[25] Zahari, M., Madun, A, Ahmad Tajudin, S. A, and Sahdan, M. Z. (2019). 'Assessment of ground subsidence potential at problematic culvert on expressway: Case study using Electrical Resistivity Tomography (ERT) and Ground Penetrating Radar (GPR)', Journal of Applied Geoscience and Built Environment, 1(1), pp. 1-4

[26] Bery, A. A., \& Saad, R. (2012). Correlation of Seismic P-Wave Velocities with Engineering Parameters (N Value and Rock Quality) for Tropical Environmental Study. International Journal of Geosciences, (3), 749-757 